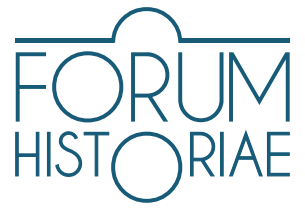

\title{
JONSSONOVÁ, Pavla. Devět z české hudební alternativy osmdesátých let. Praha : Karolinum, 2019 \\ (Recenzia/Review)
}

\author{
Jan Bárta
}

\section{RECENZOVANÁ PUBLIKÁCIA:}

JONSSONOVÁ, Pavla. Devět z české hudební alternativy osmdesátých let. Praha : Karolinum, 2019, 218 s. ISBN 978-80-246-4328-1

DOI: https://doi.org/10.31577/forhist.2020.14.1.10

Č eskoslovenská 80. léta v hudbě nejsou mnohdy nahlížena jako dekáda z nejhodnotnějších a nezřídka jsou jim přisuzovány veskrze negativní př́ívlastky. Bylo by však zavádějící nazírat na uvedenou epochu jen prizmatem únikové a často obsahově vyprázdněné pop-music, nebo - parafrází s dobovou kritickou glosou v textu pražské novovlnné skupiny Nahoru po schodišti dolů band - jen oním „českým kotvalděním-hložením“. Již zesnulý muzikolog, hudební publicista a v uvedené době rovněž výrazný organizátor hudebního života neoficiální scény, Vojtěch Lindaur chápal po právu sledovanou dobu jako nadmíru zajímavou, tvůrčím př́stupem plodnou a originální a připodobňoval zakladatelskou horečku i překotný vznik nových skupin hlavně ve druhé polovině 80. let jako srovnatelnou jen s lety šedesátými. Patrně netřeba nijak zvláště rozvádět, že uvedené Lindaurovo hledisko není $\mathrm{v}$ žádném případě ojedinělým a mimo zmiňované sféry oficiální produkce náleží 80. léta k nejvýraznějším kapitolám domácí alternativní a rockové hudby vůbec. Právě na tuto epochu se aktuálně zaměřila rovněž monografie antropoložky a hudebnice Pavly Jonssonové.

Úvodní kontextuální pole, v němž se bude výklad dále pohybovat a jež zmiňuje autorka rovněž v úvodních částech své práce je následující: V roce 1979 bylo Jazzové sekci umožněno uspořádat poslední IX. Pražské jazzové dny. S počátkem deváté dekády bylo možno vysledovat narůstající tlak ze strany domácích orgánů vůči alternativní hudební scéně, což vrcholilo v roce 1983, kdy ve stranickém týdeníku Tribuna pod fiktivním pseudonymem Jana Krýzla vyšel na popud nejvyšších stranických míst pamfletický článek Nová vlna se starým obsahem, k jehož důsledkům náležela mnohovrstevnatá represe zejména vůči amatérským kapelám hrajícím hlavně punk a tzv. českou novou vlnu. $\mathrm{V}$ roce 1986 proběhl pak soudní proces, kdy byla s konečnou platností definitivně zlikvidována Jazzová sekce a její čelní aktivisté byli v politicky motivovaném procesu vystaveni trestně-právnímu postihu a uvězněni. S koncem 80. let a pokračující korozí „normalizačního“ režimu lze 
pak hovořit jednak o snahách kontrolovat uvedené hudební proudy (organizačně např. v platformách, kterými byly Rockfesty) a jak napovídají dosavadní výzkumy, tak bezprostředně před revolucí přibližovala se oficiální stanoviska i jednání moci patrně nakonec už i jisté rezignaci.

Lze konstatovat, že v základních konturách je uvedený fenomén muzikologicky i historiograficky již rámcově zpracován. Ze stěžejních textů přehledové literatury byla první relevantní studií mapující scénu 80. let práce Excentrici v př́zemí, čítala více než čtyři desítky medailonů tehdejších kapel včetně úvodního programového eseje hudebního teoretika a publicisty Josefa Vlčka Nová vlna - př́běh dušičkový. ${ }^{1}$ Souhrnné povahy je kapitola k hudbě taktéž z Vlčkova pera v rozsáhlé syntéze Alternativní kultura ${ }^{2}$ a z historiografické perspektivy zaměřil pozornost $\mathrm{k}$ fenoménu rockové hudby zejména Miroslav Vaněk. Jednak ke sledovanému tématu průkopnickou studií Kytky v popelnici , ve které se jako první profesní historik vyjadřoval k zákulisí a okolnostem kampaně kolem článku Nová vlna se starým obsahem, a potom zejména komplexně v syntéze Byl to jenom rock'n'roll? Hudební alternativa v komunistickém Československu 1956 - 1989. ${ }^{4}$ Kromě toho vznikl seriál České televize Bigbít (1998), jenž činí společně s jeho internetovou platformou jednoznačně nejobsáhlejší faktografickou základnu mapující v celistvosti dějiny české a slovenské rockové hudby. ${ }^{5}$ Předobrazem seriálu se stala stejnojmenná kniha Vojtěcha Lindaura a Ondřeje Konráda Život v tahu aneb 30 roků rocku. ${ }^{6}$ Výraznou dokumentární a faktickou hodnotu mají i dějiny punku a hardcore Kytary a řev aneb co bylo za zdī anebo Chadimova pamětnická Alternativa ${ }^{8}$, cúlící však zejména $\mathrm{k}$ počátkům nezávislých žánrů v 70. letech. Z historiografie se tematicky přibližují rovněž četné práce Přemysla Houdy, sice k dějinám folku ale rovněž i byrokratickému rámci existence tehdejších interpretů (např. Šafrán: Kniha o sdružení písničkářũ $)^{9}$, anebo Petra Blažka s Filipem Pospíšilem k historii vlasaté mládeže nebo happeningům u Lennonovy zdi v Praze. ${ }^{10}$ Nabízí se tedy zákonitě otázka, v čem je uvedená monografie inovativní, nahlíží na fenomén alternativní hudby odlišně, do kterých neprobádaných oblastí její vyprávění směřuje? Úvodem lze rovnou konstatovat, že kniha je přínosná zvláště původností interpretace,

1 VLČEK, Josef - OPEKAR, Aleš. Excentrici v př́zemí. Praha : Impuls, 1989. Publikace je hodna pozornosti i dodnes živým a atraktivním grafickým provedením.

2 ALAN, Josef (ed.) Alternativní kultura: Příběh české společnosti 1945 - 1989. Praha : Nakladatelství Lidové noviny, 2001.

3 VANĚK, Miroslav. Kytky v popelnici. Punk a nová vlna v Československu. In VANĚK, Miroslav a kol. Ostrůvky svobody: Kulturní a občanské aktivity mladé generace v 80. letech v Československu. Praha : Ústav pro soudobé dějiny AV ČR - Votobia, 2002, s. 175-235.

4 VANĚK, Miroslav. Byl to jenom rock'n'roll? Hudební alternativa v komunistickém Československu 1956 1989. Praha : Academia, 2010.

5 Srov. http://www.ceskatelevize.cz/specialy/bigbit/

6 LINDAUR, Vojtěch - KONRÁD, Ondřej. Život v tahu aneb 30 roků rocku. Praha : Tvorba, 1990.

7 FUCHS, Filip. Kytary a řev aneb co bylo za zdí. Punk a hardcore v Československu pred rokem 1989. Praha : Papagájův Hlasatel, 2002.

8 CHADIMA, Mikoláš. Alternativa Svědectví o českém rock \& rollu sedmdesátých let (od rekvalifikací $k$ „nové vlně se starým obsahem"). Brno : Host, 1993.

9 HOUDA, Přemysl. Šafrán: Kniha o sdružení písničkářơ. Praha : Galén, 2008

10 POSPÍŠIL, Filip - BLAŽEK, Petr. Vrat’te nám vlasy: První máničky, vlasatci a hippies v komunistickém Československu. Praha : Academia, 2011; BLAŽEK, Petr - LAUBBE, Roman - POSPÍŠIL, Filip. Lennonova zed' v Praze: Neformální shromáždění mládeže na Kampě. Praha : Ústav pro soudobé dějiny AV CR, 2003. 
reflexí neprávem opomíjených aspektů tvůrčích cest jednotlivých osobností scény nebo přímo i některých postav jako takových.

Pozičně za textem stojí autorka vystupující z dvojice polí. Jde jednak o autorku-antropoložku, čemu odpovídá metodologické ukotvení práce, rozpracovávající jednak etnomuzikologická východiska Bruno Nettla ${ }^{11}$ nebo Allana Merriama ${ }^{12}$, a jak ona uvádí, tak dále zacházela s terénně antropologickými zásadami Stone Sunteinové a Chiseri-Straterové ${ }^{13}$ a cílila na spojení s co největším množstvím rozdílných pohledů (srov. s. 203). Potýkala se s problémem, že antropologie (ani hudební) necílí primárně na minulost, a tak voleným nástrojem k rekonstrukci a žádanému pohledu zpět je nakonec dominujícím způsobem zejména orální historie, posouvající práci k mikrohistorické perspektivě. Mimo důrazu na „malé dějiny“, zprostředkování hlasu opomíjeným a jejich subjektivnosti je pro ni jednou $\mathrm{z}$ ústředních výzkumných otázek působení estetické zkušenosti na jedince, $\mathrm{v}$ tom vychází mimo jiné rovněž z Hanse-Georga Gadamera. ${ }^{14}$ Zároveň však kromě toho Jonssonová v roce 1980 stála u zrodu hudební skupiny Plyn a následně důležitého souboru pražské klubové scény 80. let, kapely Dybbuk. Propojení dvojice perspektiv, vědkyně a současně aktivní aktérky - insiderky, s sebou jistě neslo řadu úskalí. Jonssonová také svou příslušnost k alternativnímu proudu otevřeně deklaruje, avšak zasvěcený osobní vhled i promyšlené výstavba i argumentace a zejména zjevně patrná poctivost autorčina přístupu svědčí o kombinaci více než funkční.

Úvodní část je souhrnné povahy, nicméně účelem je plně dostačující. Autorka abstrahuje zdařile podstatné a kapitoly jí slouží jako východisko dalšího výkladu, resp. k zasazení následujících biografických portrétů. Jonssonová cílí na obecnější souvislosti dobové situace a rekapituluje rámcově stěžejní dobové diskuse (napřs. odezvy Mikoláše Chadimy, Josefa Vlčka a Lubomíra Dorůžky v reakci na článek Tribuny). Zmiňuje význam kontaktů s britským hudebníkem Chrisem Cutlerem a společenstvím západoevropských kapel sdružených v Rock in Opposition, zaměřuje se na vztah neoficiální scény k programově odlišnému a staršímu undergroundu, na vztah profesionální a amatérské části hudebního spektra („postoj versus řemeslo", s. 31) a nemalý prostor věnuje aktivitám a významu Jazzové sekce. Ve spojitosti s tím se však výrazněji nevyjadřuje k pozdějším a eticky sporným otázkám vyvstalých s kontakty jejích vedoucích představitelů s StB. Odkazuje na literaturu k obou stranám sporu a deklaruje, že předmětem práce není rekonstruovat ani posuzovat jednotlivé verze kauzy spolupráce a zdůrazňuje zejména záměr poukázat na pozitivní úlohu např. Karla Srpa pro rozvoj alternativní scény (s. 44)..$^{15}$ Ostatně v celé knize směřuje hledisko Jonssonové dominantně ke sféře

11 NETTL, Bruno. Encounters in Ethnomusicology: A memoir. Detroit : Harmonie Park Press, 2002; NETTL, Bruno. Nettl's Elephant: On the History of Ethnomusicology. Urbana : University of Illinois Press, 2010.

12 MERRIAM, Alan P. The antropology of music. Evanston : Northwestern University Press, 1964.

13 STONE SUNSTEIN, Bonnie - CHISERI-STRATER, Elizabeth. Field Working. Reading and Writing research. Boston : Bedford/St. Martin's, 2007.

14 GADAMER, Hans-Georg. Pravda a metoda I. Nárys filosofické hermeneutiky. Praha : Triáda, 2010.

15 K tématu Jazzové sekce souhrnně viz např:: KOUŘIL, Vladimír. Jazzová sekce v čase a nečase 1971 - 1987. Praha : Torst, 1999; TOMEK, Oldřich. Akce JAZZ. In TÁBORSKÝ, Jan (ed.) Securitas Imperii 10: Sborník k dokumentaci vztahů čs. komunistického režimu $k$ „vnitřnímu nepříteli“. Praha : Úřad dokumentace a vyšetřování zločinů komunismu, 2003, s. 240-332. 
kulturní, nikoliv té mocenské, státně-institucionární apod. Z podstaty zvoleného př́stupu ji tedy primárně nezajímají analýzy strategií režimu represivního charakteru směrem k non-konformním hudebním aktivitám, zákazů koncertů, rušení zřizovatelských smluv, postupu ze strany StB apod., v českém kontextu často již dobře zmapovanými např. Ústavem pro studium totalitních režimů a dalšími studiemi. Neznamená to však, že tyto strategie nejsou v textu př́ítomny. V knize dále zpovídaní aktéři se k urputným zákazům, komplikacím a snahám o možnost vyjádření vracejí opakovaně a z logiky tehdejší reality tak konflikty se státem a jeho úřady celkem přirozeně prostupují jako jedna z ústředních a přirozených linií. (Chadimova nebo Zajičkova životní dráha jsou více než vypovídajícími doklady). Jen pro úplnost doplňuji, že v uvedené úvodní části zabývajícími se platformami je cenné a doposud nezpracované např. rovněž zmapování Hokkaido recording company (HRC) - společenství vydávající alba alternativně k oficiálním společnostem Supraphon a Panton - a jehož aktivity přibližuje zejména na základě rozhovorů s Václavem Kř́stkem, jedním ze zakladatelů a čelných postav HRC (Křístek stál režijně ve druhé polovině 90 . let rovněž u zmiňovaného cyklu České televize Bigbít). Ve zkratce HRC fungovalo na bázi konceptu dočasných autonomních zón, užívalo vlastního neologického jazyka, anebo vydávalo post-punkový zin Hokkaido news.

Z hlediska tématu práce je pro úvodní část přirozeně klíčová definice „alternativy“. Autorka odkazuje na hodnotově formující text kritika Josefa Vlčka Úkoly české alternativní hudby vydané ve Zpravodaji devátých Pražských jazzových dnů 1979. Osvětluje generační zkušenost části tehdejší mládeže hrát, vyjádřit se. Sociolog Jiří Svítek se vyslovoval o uvedené generaci jako o první, jež vyrostla v reálném socialismu, nebyla zasažena traumatem svých rodičů a rokem 1968 a s nastupující dospělostí se začala vůči žité skutečnosti specificky vymezovat. Ve spojitosti s amatérskými kapelami první poloviny 80 . let hovoří nemalý počet muzikologů o tzv. české nové vlně. Navzdory dodnes trvajícím terminologickým nejasnostem kolem samotného pojmu lze konstatovat, že se jednalo o hudebně sice nesourodý proud neprofesionálních skupin, jež nicméně spojovalo časté užívání humoru a smíchových nebo sarkastických podob sdělení. Vyznačovaly se dále výstřední jevištní prezentaci, výraznými kostýmy a líčením, propojováním s divadelními a happeningovými formami. Mezi specifické rysy náležel v neposlední řadě rovněž intuitivní návrat $\mathrm{k}$ češtině jako volenému prostředku sdělení - na rozdíl od předtím idealizované angličtiny anebo instrumentálního hraní alternativních tvůrců 70. let, coby obranné strategie před výtkami k textům ze strany kulturních komisí. Český jazyk ve smyslu hravosti, jež nabízel, se projevil přirozeně jednak na úrovni textů, ale také i názvů skupin (Ještě jsme se nedohodli, Krásné nové stroje, Mama bubo, Třírychlostní pepíček, Jasná páka...). K uvedenému fenoménu se rekapitulačně vyjadřoval na úrovni programového eseje Nová vlna - př́běh dušičkový již zmiňovaný Josef Vlček (Excentrici v př́zemí, 1989). Směrem k soudobému zájemci je na místě i odkaz na unikátní filmový dokument Hudba 85. Jednalo se o dvouhodinový dokumentární film mapující zejména kapely pražské klubové scény, který v roce 1984 natočili tři filmoví a hudební nadšenci Alexej Guha, Vladislav Burda a Petr Ryba. Primárním záměrem, který sledovali, bylo uchovat 
na film koncerty skupin, u nichž nebylo jisté, zda budou mít v budoucnu ještě šanci hrát, přičemž záznam plastickým způsobem zprostředkovává v rovině vystoupení zmiňovaných kapel i pokusů o videoklipy část tehdejší atmosféry i jejich tvůrčí originality. ${ }^{16}$ Pamětnicko-hráčská zkušenost Jonssonové, ale i velké části nezávislé scény non-konformních kapel 80 . let, a nakonec i záběru knihy samotné se s fenoménem tzv. nové vlny výrazně překrývají, nicméně autorka sleduje nakonec pole širší a cílí směrem ke komplexněji chápané hudební „alternativě“. Tu vymezuje jako „historický fenomén 80. let reagující na kritický stav populární kultury, způsobený cenzurou a ideologickými omezeními“"(s. 18). Z dílčích znakủ jí přisuzuje dále charakteristiky, parafrázujme: Hudba vznikala v reakci na ohrožení a nesvobodu; užívání češtiny; inovativní poezie jdoucí za původní vzory; vlastní tvorba, osobitost a autenticita; žánrově široký záběr od experimentu, přes avantgardu k punku a reggae a dalším stylům ale vždy spojené s rockovou poetikou; alternativní dramaturgové; hudba se musela odlišovat od mainstreamu. Takové volnější hledisko jeví se jako štastné, protože sice přesně vymezená, avšak dalšími kategoriemi přesto méně svázaná definice „alternativy“ dává autorce rovněž širší prostor, a tak se do jejího výkladu vejdou i postavy typu undergroundového básníka Pavla Zajíčka, anebo autority tehdejší scény a výrazného inspirátora, kterým byl Mikoláš Chadima.

Samotným jádrem knihy (obsaženým ostatně i v jejím názvu) je pak jednoznačně devět sond do hudebního života, resp. devět biografických mikroportrétů jeho čelných postav vystavěných na rozhovorech. Autorka upozorňuje na vědomou subjektivnost při jejich výběru (s. 201). Dle pořadí v knize dané výstavbou celkové argumentace je výslednicí výčet: Pavel Richter, Miroslav Wanek, Karel Babuljak, Pavel Zajíček, Mikoláš Chadima, Petr Váša, Marka Míková, Oldřich Janota a skupina Ženy. Před realizací domluvených interview zemřeli Filip Topol (Psí vojáci) anebo Zdeněk Lorenz (industriální OZW). Užitou metodou volila orálně-historické formy životopisných vyprávění, což lze v současné době oborově označit za upřednostňovaný př́stup, a přestože nelze generalizovat, přepouští orální historie strukturované tematické tázání spíše poli publicistiky. Z rozhovorů pak autorka skládala vlastní biografická vyprávění, kdy z hlediska struktury rámují její hlavní text citace zejména částí užitých výpovědí. Výhody výše uvedené insiderské pozice autorky se zde projevila zejména $\mathrm{v}$ důvěře narátorů plynoucích z osobních, často mnoholetých vazeb. Rozhovory doplnila dochovanými prameny, často fanziny, plakáty, pracovala s dobovými nahrávkami a záznamy. Z hlediska sledovaného působení estetické zkušenosti na jedince směřuje výklad u všech ke konkrétnímu tvůrčímu subjektu, interpretovi, ale je zároveň prokládán kontextualizačními a zobecňujícími exkurzy do dějin umění.

$V$ rámci portrétovaných osobností nelze než s povděkem kvitovat kapitolu věnovanou Miroslavu Wanekovi, jednak zakladateli punkových F.P.B. (jazyková hříčka Fourth price band, čtvrtá cenová skupina odkazující na nejnižší kvalitativní kategorii někdejšího pohostinství), ale v současnosti zejména vedoucí postavě 
skupiny Už jsme doma (UJD). Zejména proto, že těžko bychom hledali v českém kontextu z hlediska experimentální invence zajímavější a zároveň s tím rovněž i ve světě úspěšnější kapelu, než jsou právě původně severočeští UJD. Jedna z nejoriginálnějších českých skupin, jež je zároveň žánrově jen obtížně zařaditelná - klasifikace oscilují jen velmi volně kolem kategorií jako avantgardní nebo intelektuální punk, jazz-punk, post-punk, progressive a alternative rock - koncertuje aktivně dodnes a má své posluchače kromě těch domácích a z Evropy rovněž v USA (více než dvě desítky koncertních turné) nebo Japonsku. Navzdory významu UJD je s podivem, že ani na poli historiografie nebo hudebních věd a dalších př́ibuzných oborů nevznikla dosud monografie, jež by se komplexním způsobem zaměřila na existenci uvedené skupiny. Existují sice dílčí práce a antologie textů, z nichž nejvýznamnější je patrně souborný textový výbor doplněný několika interview Výlov šuplíka ${ }^{17}$, nicméně relevantní souhrnná práce zde doposud schází. Jonssonová, sice na malém prostoru srovnatelném s ostatními portrétovanými, přesto takový vhled zprostředkovala.

Za vývojem Wanekova svébytného tvůrčího rukopisu nalézá spojnice s předválečnou avantgardou, konkrétně dadaismem, surrealismem i expresionismem. Ve spojení s punkem upozorňuje na jeho překračování limitů punkové jednoduchosti (zhudebňovali např. Kafku) i na celkový přístup, kdy hudbu vnímal jako nástroj, jak zprostředkovat poezii. Okazuje rovněž na brikoláž Claude-Lévi Strausse, ve smyslu použití nalezených materiálů a jejich nového invenčního poskládání, v kontextu punku projevující se např. ve vizualizaci a vnějších znacích punkového rebelství (řetězy, špendlíky, přeneseně účesy, divoký tanec pogo) a upozorňuje $\mathrm{v}$ rámci toho jednak na Wanekovu originalitu a dále i proměny $\mathrm{v}$ jeho uměleckém přístupu, směřujícímu od původní brikoláže až k současnému tvůrčímu perfekcionismu. Výrazně přínosnou je rovněž část cílící na Wanekem spoluzaložené a dnes již částečně pozapomenuté patafyzické kolegium - společně napřs s básnířkou Svatavou Antošovou nebo literátem Eduardem Vackem vydávali časopis PAKO a Jarryho program se stal nakonec širším myšlenkovým rámcem Waneka i větší skupiny umělců sdružených kolem kolegia s četnými následovníky. ${ }^{18}$ Vlček označil v dokumentu Hudba 85 za hlavní město československého punku severočeské Teplice. Na pozadí ekologicky zdevastovaného regionu lze za estetickou zkušeností nalézat rovněž anglický punkový slogan „No future“, avšak u Waneka v nikoliv nihilistickém významu, ale v jeho obrácení a smyslu pozitivního programu vedoucího k nápravě. Po jeho občanském angažování v roce 1989 pokračoval hudebně se stále úspěšnějšími UJD a také i producentsky směrem k dalším skupinám (např. i Dybbuku). Na uvedeném místě Jonssonová zároveň výrazně plasticky ilustruje proměny a specifika domácí scény po roce 1989 , kdy se hlad po alternativě u publika spojoval s krátkodobou přízní nahrávacích společností, jež vstupovaly na rodící se trh, a kdy prvotní euforii střídala postupně jistá deziluze spojená s komercionalizací prostředí a návratem dominujícího středního proudu.

17 WANEK, Miroslav. Výlov šuplíka. FPB. Už jsme doma. Editoval Jaroslav Riedel. Praha : Mat'a, 2012.

18 Vackovu reflexi uvedených aktivit vedoucích v roce 1986 nakonec až k jeho absurdnímu uvěznění viz rovněž např. v pamětnickém textu: VACEK, Eduard. Československá patafyzická republika. Webová platforma Revue Babylon, https://babylonrevue.cz/kukacci-vejce/. 
Pakliže autorka uvádí v závěru předmluvy, že „kniha má přispět $k$ zachycení té doby" (s. 10), tak zejména právě i uvedený vhled do porevoluční praxe je neméně cenný a výrazně obohacující.

U energického hudebníka, „fyzického“ básníka a performera Petra Váši lze inspirační zdroje vysledovat jednak z širokého pole utvářeného jeho vysokoškolským studiem dějin umění (gotické umění, Picasso, česká moderna, kubisté Čapek s Kubištou a další) ale rovněž vliv intelektuální rodiny (dědečkova disertace o Březinovi a Nietzschem) a dále vlivy rockové (Rolling stones, z domácích Jasná páka...), nebo i folk-rockové (Mišík). Podobně určující jako v případě Jonssonové označoval vliv bezprostředního okolí hudební komunity. Vášovy skupiny Z kopce a (po zákazu) později Ošklid vzešly z brněnské scény, za jejíž klíčovou postavu platila vedoucí klubu Musilka a organizátorka tamějšího dění Lenka Zogatová. ${ }^{19}$

Se skupinou Z kopce rozpracovával Váša na samém konci 80. let koncept nudy, nicméně způsobem, jak on sám napsal, aby se písničky o nudě lidem líbily. Jako příznačná se jeví reakce vedoucího tajemníka Jihomoravského kraje: „My to tady čtyřicet let budujeme a oni se nudí", dokládající skutečnost, že zdánlivě odosobněné hledisko, komentování nudy nezúčastněným jazykem ve stylu bezobsažných proklamací z Rudého práva, bylo novou originální strategií, již na rozdíl od přímé kritiky režimu bylo obtížné zakazovat (s. 151). Zároveň je uvedená kapitola částí výrazně odhalující vnější limity pro existenci a prosazení tvưrčí svobody na pozadí s „perestrojkovým“ pnutím a od něj odvislých změn, jež rozhýbávaly rovněž výrazné postavy z řad organizátorů, hudebních publicistů a teoretiků a dalších nadšencủ. Dokladem a charakteristickým fenoménem druhé poloviny 80. let byl tak např. festival Rockfest. Organizován byl pod záštitou SSM (Socialistický svaz mládeže), přičemž dějiště jeho finální přehlídkové části pro rockovou hudbu tak netypické, jako byl zvolený Palác kultury v Praze, jako by pro uvedenou dobu symbolicky odráželo veškeré absurdity a rozpory ve vztahu sféry kulturní s tou mocenskou. Festival odpovídal někdejšímu obratu „dát rocku zelenou“ a zjevné reflexi nejvyšších míst, že pakliže selhaly pokusy stále rostoucí živelnou popularitu nezávislé hudby potlačit, bude alespoň učiněn pokus o její kontrolované usměrnění. Uvedené snahy byly však zároveň souběžně nabourávány např̀ tím, že hned pro první ročník 1986 se stali dramaturgy Rockfestu právě Zogatová s Vlčkem a Lindaurem, kteří se rozhodli využít festivalu k legalizaci alternativní kultury jako takové. Z kopce po jejich intervencích směrem k organizátorům na uvedeném ročníku nejenže vystoupili, ale nakonec i zvítězili, co o rok později zopakoval Váša i se skupinou Ošklid. Před pokračujícími postihy se jej jakožto vítěze zastal Mladý svět a oporu nalezl posléze i na stránkách Melodie a Gramorevue. Skupině nakonec vyšla u Pantonu EP v edici Rock debut a v roce 1989 se Zogatové podařilo prosadit i vydání LP. Všem biografickým črtám v knize je společné

19 Zogatová proslula mimo jiné pořádáním festivalových Valných hromad nebo také např. v roce 1985 úspěšně utajeným koncertem Nico, původně západoněmecké zpěvačky skupiny Velvet underground, o jehož zopakování se následně pokusil i tehdy dramaturg pražského kulturního domu Opatov Vojtěch Lindaur, avšak již se zásahem veřejné bezpečnosti, načež byl koncert ukončen a Lindaur byl z Opatova propuštěn. Kauzu obou vystoupení podrobně zpracovala historička Hana Zimmerhaklová (ZIMMERHAKLOVÁ, Hana. Nico, legenda hudebního undergroundu, v Brně a v Praze: Ke koncertování zahraničních hudebníků v komunistickém Československu. In Soudobé dějiny, 2011, roč. 18, č. 3, s. 414-436). 
nápadité pointování jednotlivých částí i jejich promyšlené propojování do větších celků. U Váši, vykonávajícího aktuálně základní vojenskou službu, náleží k takovým funkčním rozzuzlením např. zakupování uvedených časopisů s pochvalnými recenzemi Jiřího Černého a Vojtěcha Lindaura, anebo situace, kde popisuje: „Seděli jsme v hospodě a z rádia se ozvalo: Jde to všechno nějak z kopce [...]. To slyšet z komunistického rádia, ř́lkali jsme si, to bude revoluce..." (s. 147). V 90. letech se Váša profiloval zejména performersky ${ }^{20}$ a od konce dekády opět i hudebně s dodnes existující skupinou Ty syčáci.

Přestože v případě undergroundu lze hovořit díky jeho přímé spojitosti se vznikem Charty 77 a následné provázanosti s politickým disentem o tématu, na něž se domácí historiografie od 90. let zaměřila již více než zevrubně, tak rovněž v případě Pavla Zajíčka přichází Jonssonová s původní interpretací portrétovaného. Hudebník, textař, básník a společně s Milanem Hlavsou spoluzakladatel skupiny DG 307, je postavou nahlíženou příznivci hnutí v mnohém jako legendární. Autorka jej vykresluje opět směrem k postižení jeho dílčích tvůrčích zdrojů a inspirací, k nimž kromě undergroundových východisek, Jirousových a Bondyho textů patřily rovněž i surrealismus, dada a také víra. Skutečnosti, že Zajíček náležel v rámci tzv. Pražského procesu z roku 1976 ke skupině odsouzených, stejně jako to, že po svém propuštění byl již jako signatář Charty 77 vystaven tlaku StB v rámci akce „Asanace“ a nakonec volil cestu nucené emigrace, jsou dostatečně známy. Hodné pozornosti je však zprostředkování Zajíčkovy desetileté zkušenosti s exilem (odešel do Švédska a později do New Yorku) a dále obtížím s jeho porevolučním návratem. Autorka dává Zajíčkovi prostor vyjádřit se k pocitům vzájemného odcizení a neporozumění ve vztahu subjekt, emigrant - domov, domácímu ignorování života ve vyhnanství a v důsledku ústícímu i do neschopnosti jedince k okamžitému návratu zpět do vlasti, k nemožnosti kontinuálního navázání. Autorka nalézá styčné plochy s Kunderovým antioddyseovským mýtem (román Ignorance, 1999) a rozvádí jej šířeji k zobecněním emigračního prožitku. Uvedené osobní Zajíčkovo trauma vystupuje tak jako jeden z ústředních motivů jeho portrétu a otevřeností i subjektivitou sdělovaného dodává výpovědi nemalé síly (zejm. s. 117-119).

Podobně jako u Zajíčka, tak rovněž portrét Marky Míkové figuruje v pozici jednoho z nejintimnějších, dáno osobní vazbou k autorce jako spoluhráčce z jedné skupiny. Není bez zajímavosti, že hraní v rockové kapele Míková, rovněž loutkoherečka a režisérka, definovala jako jeden ze způsobů obranné strategie před pozorností veřejnosti po její roli ve filmové pohádce. Kapitola se dále přirozeně výrazně překrývá s kapelou Dybbuk, kde se jako v nesčetných dalších případech jednalo rovněž o původně amatérskou skupinu, a to nikoliv jen ve smyslu úředním, tedy neprofesionální bez nároku na honorář - ale amatérskou také i z hlediska počátečních instrumentálních nedostatků kombinovaných však s hráčským

20 Věnoval se tzv. fyzickému básnictví. Autor popisuje jím uplatňovaný „žánr“ v učebnicové a manifestové podobě: VÁŠA, Petr. Fyzické básnictví. Brno : Host, 2011. 
nadšením, entuziasmem a důrazem na autenticitu vyjádření. Se zjevně punkovými kořeny se skupina vyznačovala syrovým zvukem i neotřelou poetikou a jevištní prezentací. Skupina, jejíž styl žánrově charakterizoval např. Vojtěch Lindaur jako „nadrzlou kytarovku“, byla však dále hodna pozornosti ještě z jednoho hlediska: Jednalo se totiž člensky o čistě dívčí těleso, čemuž odpovídala také i část jejího textového záběru anebo specifického výraziva (např. písně Paní I. - III., Ale čert to vem, Rebelka bez příčiny, a další). S přibývajícími zkušenostmi se zvuk kapely tř́íbil, jako v případě jiných se stával vyzrálejším a kapela existovala ve významné pozici místní scény až roku 1988, kdy část hudebnic přešlo do stylově již odlišného souboru Panika. Po roce 1989 vydal Dybbuk souhrnné album své někdejší tvorby (Poletíme, ale čert to vem, 1991) a v obnovené sestavě realizovala skupina počátkem 90 . let rovněž rozsáhlé koncertní turné. S personálními obměnami vystupuje aktivně jádro skupiny dodnes pod názvem Zuby nehty.

Navzdory proklamativní distanci členek Dybbuku vůči západní ženské alternativní scéně, lze přesto vysledovat intuitivní spojitost s punkovým obratem ve smyslu prosazení žen - interpretek a odlišnosti rolí, jež zaujímaly. Tedy v posunu zpěvačky - objektu od jen vnějškově reflektovaného do pozice aktivního subjektu, v důrazu směrem ke sdělovanému, v odmítnutí žádaného ideálu krásy určovaného módními žurnály. Redefinování kategorie feminity bylo zjevně zároveň v určitém napětí s připisovanou ženskou identitou Dybbuku (anebo analogicky západních skupin jako např. The Slits anebo The Raincoats). Autorka se tak nakonec vyjadřuje k jednomu z citelných neuralgických bodů jejich existence, totiž stereotypním klasifikacím, resp. tomu že členky se musely potýkat s referencemi, že se jedná o „ženskou, dívčí, dámskou“ skupinu. Ve vztahu k tomuto problematickému hledisku jsou pak výrazně vypovídající citovaná korektivní vyjádření Petra Váši anebo Miroslava Waneka.

Není v možnostech ani ambicí textu vyjádřit se souhrnně ke všem, a tak se omezí v případě portrétu tak významné postavy, jakým byl „rebel“ Mikoláš Chadima (aktivista Jazzové sekce, signatář Charty 77, lídr Extempore a MCH bandu) na lakonické konstatování jeho zcela zásadního vlivu směrem k tehdy mladším souputníkům. A dále z „méně známých“: Podobně jako Chadima byl i Oldřich Janota, zejména pro svou poezii, vnímán v pozici výrazného inspirátora amatérských tvůrců. Janotův symbolický jazyk, folk ovlivněný duchovními zdroji a archetypálními vyprávěními i hudební minimalismus a experiment směřovaly Janotu do pozice, kdy v širším povědomí zůstával po většinu své tvůrčí dráhy však v jistém pozadí - spíše s komornějším projevem a s tím spojenou i nemasovou účastí publika. Jeho do určité míry okrajové postavení ve vztahu k široké komunitě posluchačů nabourává tak poněkud paradoxně i jeho patrně veřejně nejznámější počin, kterým se stala píseň Zrychlený vlak. Málo známou skutečností je totiž to, že jako původně Janotovu ji převzala a následně v taneční podobě i zpopularizovala skupina Mňága a Ždorp, přičemž skladba se stala posléze i jednou z klíčových v celkové tvorbě kapely. Jonssonová uvádí Janotovu reflexi pozadí jejího 
vzniku: „Byla to reakce na dobu po Chartě. Ta píseň bylo o tom, že když jsou cíle znemožněný, i cesta sama o sobě je velikým cílem, že pojd'me hrdě s hlavou vztyčenou. " Z textu vystupuje i v tomto případě pozměněná domácí hudební realita po roce 1989 i obecnější trend posunu v chápání významu s ohledem na okolní kontext. K tomu Janota dodával: „Proslavila se proto, že jí Petr Fiala vtiskl ten taneční charakter, zjednodušil ji. A to je model, co rádio v Čechách může přijmout, nemůže přijmout něco, co by posluchače zavádělo někam do nitra, neznepokojovat [...] Ani to lidé nevědí, že jsem autor, ale mě to stačí, to hrdé vědomí." (s. 184).

Janota spolupracoval rovněž s dalším z portrétovaných, Pavlem Richterem, výborným kytarovým hráčem skupin Elektrobus, Stehlík a Švehlík. Z Richterových hudebních experimentů směřujících $\mathrm{k}$ psychedelické hudbě vzešly přelomové projekty domácí alternativy jako např. Sny psychopatického děcka (Švehlík) anebo pokusy s elektronickým zvukem. Ve druhé polovině 80. let hrál jednak s brněnskou skupinou Dunaj, ale také po odklonu od rockové hudby figuroval jako zásadní průkopník ethno a world music. Jak autorka zdůrazňuje, Richterův vývoj proběhl v situaci bez dostupných nástrojů a techniky a bez kontaktu se světem. A to samé lze konstatovat rovněž v rámci další kapitoly a osoby, kdy obdobně Karel Babuljak (společně s Alešem Drvotou a Jiřím Charyparem) a skupinou Babalet stali se průkopníky reggae u nás, resp. jejich paralelní projekt Mama bubo (hlavně cíleným užíváním syntetizátorů) zcela novátorským souborem na poli elektronické hudby. Zejména v popisu počátků reggae jde o pole historickým výzkumem rovněž dosud zásadním způsobem nedotčené.

Knihu uzavírá biografie skupiny Ženy, vystavěná na interview se Zdeňkem Novákem (alias „Hmyzákem“) a Petrem Chourou (zvaným „Záchod“), dříve rovněž výrazně excentrickým tanečníkem novovlnné skupiny Krásné nové stroje. Do popředí se tu dostávají happening a nevážnost Žen a v uvedeném př́ípadě mozaiku celkového obrazu scény dotváří také značné množství dokreslujících situací a popisovaných konkrétních zážitků, často nemálo úsměvných. $\mathrm{V}$ tomto ohledu sice intenzita textu spočívá rovněž $v$ detailu, ale zaměřovat se jen na ně by bylo pohledem zjevně zavádějícím. $V$ rámci zprostředkovaných extravagancí se totiž nejedná jen o sled zdánlivě prvoplánových hospodských př́hod, jak by se zdánlivě mohlo jevit. Obraz vyrůstá a Jonssonová jej vykresluje i v tomto př́padě na výrazně intelektuálních kořenech skupiny i obou jejích členů.

Závěrečné shrnutí je tedy takové, že těžiště práce leží v souladu s jejím názvem v 80. letech, nicméně četné přesahy vedoucí výklad do dekády porevoluční jí dodávají výraznou přidanou hodnotu. Jazyk knihy je kultivovaný, na přehledových místech autorka funkčně pracuje se zkratkou a narace i celek směřují k dílčím pointám i přesvědčivým závěrům. Zároveň se však stylově jazyk knihy vyznačuje značnou čtivostí a poutavostí. K výrazným kladům náleží pak jednak její faktický a dokumentární př́nos a dále zejména rekonstrukce kulturních, nezř́íka avantgardních a dalších vlivů pro tvorbu sledovaných osobností, výzkumem často dosud zcela nepostižených, jež Pavla Jonssonová zároveň umíst'uje do kontextu 
s širší nebo zahraniční uměleckou i kulturně-historickou tradicí. Lze tak bez výhrad konstatovat, že kniha Devět z české hudební alternativy je komplexně promyšlenou a originální studií s výrazně obohacujícím a podrobným vhledem do zákulisí části české nezávislé hudební scény 80. let a pro jakýkoliv další výzkum této scény se jednoznačně zařadí mezi korpus základních referenčních prací, jež při seriózním př́stupu k tématu nelze ignorovat.

\section{Cituj:}

Bárta, Jan. JONSSONOVÁ, Pavla. Devět z české hudební alternativy osmdesátých let. Praha : Karolinum, 2019, 218 s. ISBN 978-80-246-4328-1. In Forum Historiae, 2020, roč. 14, č. 1, s. 140-150. ISSN 1337-6861. DOI: https://doi.org/10.31577/forhist.2020.14.1.10

PhDr. Jan Bárta

Ústav českých dějin

Filozofická fakulta Univerzity Karlova

nám. Jana Palacha 2

11638 Praha 1, Česká republika

E-mail: barta_jan@centrum.cz 